\title{
Changes in invertebrate assemblages inhabiting Lessonia spicata (Phaeophyceae) holdfasts after the 2010 earthquake-mediated coastal uplift in Chile
}

Cambios en los ensambles de invertebrados asociados a discos del huiro negro Lessonia spicata (Phaeophyceae) después del levantamiento costero producto del terremoto de 2010 en Chile

\author{
Karla J. Ortega ${ }^{1}$, Claudio A. Sáez ${ }^{2,4}$ and Erasmo C. Macaya ${ }^{1,3}$
}

\begin{abstract}
${ }^{1}$ Laboratorio de Estudios Algales ALGALAB, Departamento de Oceanografía, Facultad de Ciencias Naturales y Oceanográficas, Universidad de Concepción, Casilla 160-C, Concepción, Chile. emacaya@oceanografia.udec.cl

${ }^{2}$ Plymouth University, School of Marine Science \& Engineering, Faculty of Science \& Environment, Drake Circus, Plymouth, PL4 8AA, United Kingdom

${ }^{3}$ Interdisciplinary Center for Aquaculture Research (INCAR), Universidad de Concepción, P.O. Box 160-C, Concepción, Chile ${ }^{4}$ Present address: Departamento de Biología, Facultad de Química y Biología, Universidad de Santiago de Chile, Casilla 40 Correo 33, Santiago, Chile

Abstract.- On February 27th 2010, a mega-earthquake struck Chile causing coastal coseismic uplift. In this study we compared the invertebrate fauna from uplifted (UH) and non-uplifted (NH) Lessonia spicata kelp holdfasts. Multivariate analysis of the assemblage structure revealed different faunal composition between holdfasts, the anemone Phymactis clematis and the mussel Perumytilus purpuratus displayed the highest contribution to these differences, being most abundant in UH. A preference to inhabit in UH is most likely to be related to food availability and capacity to thrive with high salinity and desiccation, while $\mathrm{NH}$ became habitat for a rare primary ecological succession. The present study helps to understand ecological implications of such rare events.
\end{abstract}

Key words: Coastal coseismic uplift, kelps, associated fauna, assemblages analysis

\section{INTRODUCTION}

On February $27^{\text {th }} 2010(27 \mathrm{~F})$, one of the strongest earthquakes $\left(\mathrm{M}_{\mathrm{w}}\right.$ 8.8) in the last 150 years struck Chile along the central-southern coast (Farías et al. 2010, Vargas et al. 2011) causing coastal coseismic uplift of up to $\sim 3 \mathrm{~m}$ at locations in proximity to the earthquake rupture (Castilla et al. 2010, Vargas et al. 2011, Melnick et al. 2012). This event produced massive mortality of intertidal communities suddenly exposed to drastic changes in biotic and abiotic factors such as predation, desiccation, salinity and temperature stress (Castilla et al. 2010, Jaramillo et al. 2012).

Previous studies have demonstrated the effect of sudden rocky shore uplifts on kelps and its associated assemblages (Castilla 1988, Castilla \& Oliva 1990). Castilla \& Oliva (1990) observed that after a coastal uplift caused by an earthquake in 1985 in central Chile, the intertidal kelp belt expanded downwards in approximately $1 \mathrm{~m}$; moreover, the old uplifted middle-intertidal was colonized by species of barnacles, organisms characteristic of the upper-intertidal. Kelps are ecosystem bio-engineers; they are main primary producers and play an important ecological role in coastal rocky shores of temperate environments (Vásquez \& Santelices 1984, Smith et al. 1996, Smith 2000). The complex and compact holdfasts of kelps provide a valuable habitat for a high diversity of small invertebrates (Tuya et al. 2011); these microecosystems give shelter, access to food, as well as nursery and spawning sites (Cancino \& Santelices 1984, Ojeda \& Santelices 1984, Villouta \& Santelices 1986, Thiel et al. 2007). Along the central Chilean coast, the kelp Lessonia spicata is the dominant algal species in the low intertidal, and their holdfasts host high species richness (Vásquez \& Santelices 1984). This species was previously recognized as L. nigrescens until recent molecular, morphological and nomenclatural studies led to the recognition of a separate species between $29^{\circ}-41^{\circ} \mathrm{S}$ in central-southern Chile (Tellier et al. 2009, González et al. 2012).

Many studies have highlighted the use of kelp holdfasts faunal assamblages as bio-monitor following environmental perturbations (e.g., Jones 1972, Smith \& Simpson 1993, Smith et al. 1996, Smith 2000, Sáez et al. 
2012). In this study we took advantage of the coseismic uplift in Chile to study the effects of changes in the vertical positioning of the $L$. spicata belts on the structure of fauna inhabiting uplifted holdfasts (UH), to that occurring in new non-uplifted holdfasts (NH) (Fig. 1 C, D).

\section{MATERIALS AND METHODS}

The study was carried out at 'La Desembocadura', Biobío Region, Chile (3648’25.92"S, 7310’38.08"W), a site known to be uplifted by the $27 \mathrm{~F}$ mega-earthquake (see Fig.1 A,B). Along the L. spicata belt, $5 \mathrm{UH}$ separated by several metres were collected; those holdfasts were very damaged (Fig. 1D), as also observed by Castilla \& Oliva (1990) after an earthquake in central Chile in 1985. Additionally, $5 \mathrm{NH}$ were taken. In all cases and after cutting-off the stipes, $\mathrm{NH}$ and $\mathrm{UH}$ holdfasts with similar sizes (20 $\pm 2 \mathrm{~cm}$ of base diameter) were detached using a crowbar and stored in bags. Sampling was carried out 14 months after earthquake, in April 2011.

In the laboratory, holdfasts were rinsed with seawater to promote the detachment of organisms; the remnant was sieved through a $0.5 \mathrm{~mm}$ mesh and retained. Organisms were identified to the highest possible level of taxonomic resolution. We calculated the total number of species (S) and Shannon-Wiener Index ( $\left.\mathrm{H}^{\prime}\right)$. In order to compare differences, one-way ANOVA was carried out. Prior to the analyses, tests for normality (KolmogorovSmirnov test) and homogeneity of variances (Bartlett test) were performed. For multivariate analysis, data were transformed by $\log (\mathrm{x}+1)$ and a similarity matrix based on Bray-Curtis was constructed (Clarke et al. 2006). In order to graphically represent holdfast assemblages between $\mathrm{UH}$ and NH, non-metric multidimensional scaling (nMDS) was applied. Analysis of similarities (ANOSIM) was used

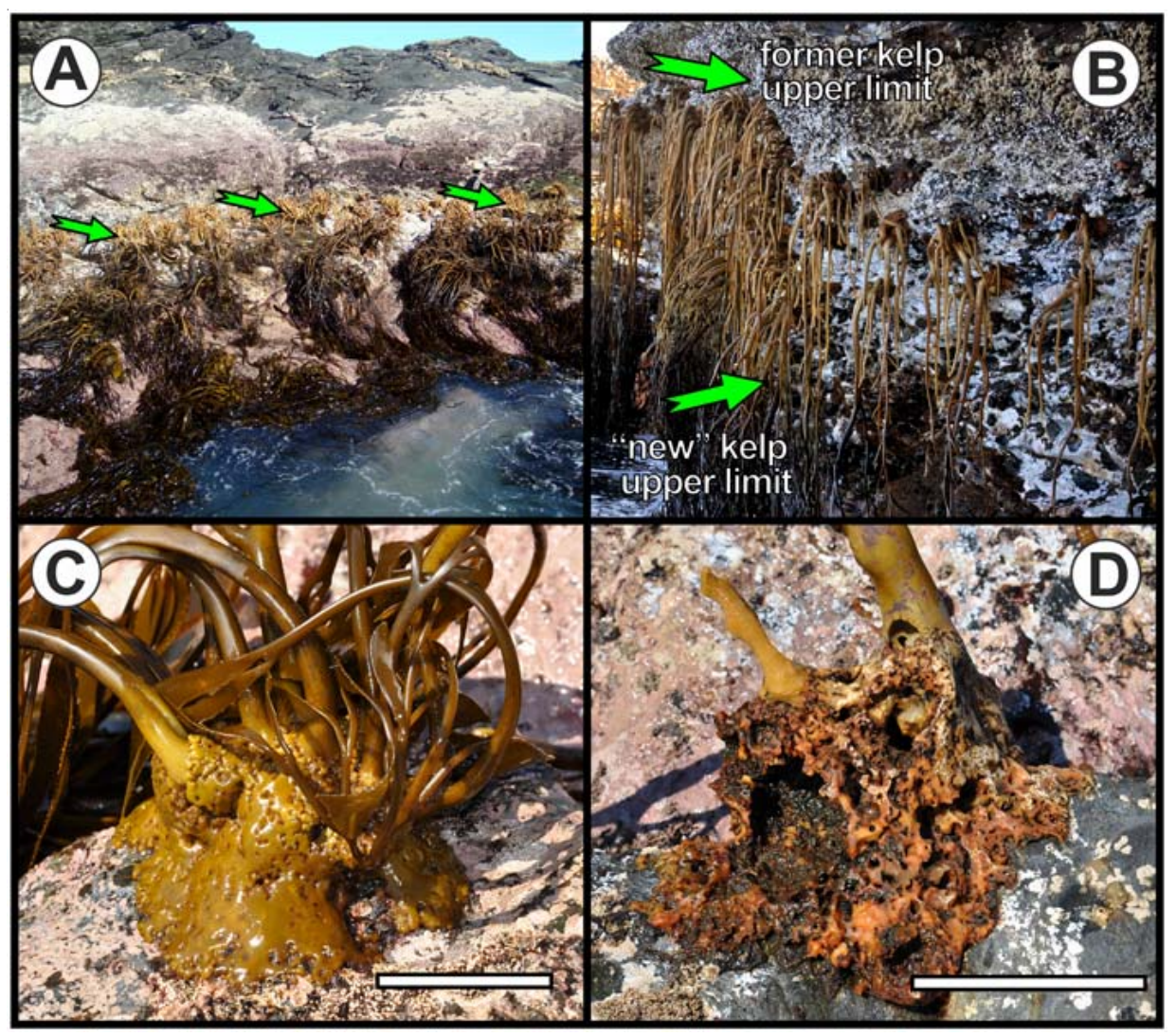

Figure 1. A) Lessonia spicata belt at sampling site 'La Desembocadura', arrows display the uplifted L. spicata individuals; B) Kelp upper limit, before and after the 27 February 2010 mega-earthquake; C) Non-uplifted L. spicata holdfast; D) Uplifted $L$. spicata holdfast $(S c a l e=10 \mathrm{~cm}) /$ A) Cinturón de Lessonia spicata en 'La Desembocadura', las flechas muestran los individuos levantados; B) Límite superior de L. spicata antes y después del mega-terremoto del 27 febrero de 2010; C) Discos de L. spicata No-levantados; D) Discos de $L$. spicata levantados $(E s c a l a=10 \mathrm{~cm}$ ) 
to identify significant differences between assemblages belonging to UH and NH. $P$-values were calculated using the Spearman product-moment correlation method with a maximum of 9999 unrestricted permutations (Clarke 1993). A similarities percentages (SIMPER) analysis was used to identify the species that contributed the most to the differences in assemblage's structure between UH and NH. All multivariate procedures were carried out using PRIMER v.6 software package (Plymouth Marine Laboratory 1997).

\section{RESULTS AND DISCUSSION}

The fauna associated with $L$. spicata holdfasts comprised 26 taxa from 5 phyla (Table 1): Annelida, Arthropoda, Mollusca, Cnidaria and Nemertea. The polychaetes had the highest number of families, with 7 representatives. In UH we documented 24 species, from 12 orders and 8 classes; whereas in NH were documented 19 species, from 12 orders and 8 classes. The faunal composition was different between the two types of holdfasts as

Table 1. Associated fauna inhabiting holdfasts of $L$. spicata, including abundance for each species, family or phylum / Fauna asociada a discos de L. spicata, incluyendo abundancia por cada especie, género, familia o phylum

\begin{tabular}{|c|c|}
\hline Uplifted Holdfasts - UH & Non-Uplifted Holdfasts - NH \\
\hline ANNELIDA & ANNELIDA \\
\hline Terebellidae (50) & Terebellidae (8) \\
\hline Nereididae (287) & Nereididae (184) \\
\hline Syllidae (36) & Syllidae (18) \\
\hline Phyllodocidae (6) & Phyllodocidae (6) \\
\hline Polynoidae (9) & Polynoidae (2) \\
\hline $\begin{array}{l}\text { Sabellariidae (13) } \\
\text { Lumbrineridae (5) }\end{array}$ & Sabellariidae (61) \\
\hline ARTHROPODA & ARTHROPODA \\
\hline Decapoda & Decapoda \\
\hline Acanthocyclus gayi (74) & Acanthocyclus gayi (12) \\
\hline Hemigrapsus cremulatus (1) & Homalaspis plana (4) \\
\hline Cirripedia (15) & Cirripedia (18) \\
\hline Isopoda $(51)$ & Isopoda (7) \\
\hline $\begin{array}{l}\text { Amphipoda (293) } \\
\text { Pycnogonida (1) }\end{array}$ & $\begin{array}{l}\text { Amphipoda (32) } \\
\text { Pycnogonida (1) }\end{array}$ \\
\hline MOLLUSCA & MOLLUSCA \\
\hline Bivalvia & Bivalvia \\
\hline Perumytilus purpuratus (1077) & Perumytilus purpuratus (82) \\
\hline Semimytilus algosus (1532) & Semimytilus algosus (828) \\
\hline Brachidontes granulata (4) & Brachidontes granulata (6) \\
\hline Gastropoda & Gastropoda \\
\hline Scurria scurra $(90)$ & Scurria scurra (17) \\
\hline \multicolumn{2}{|l|}{ Lottia orbigny (2) } \\
\hline \multicolumn{2}{|l|}{ Fissurella sp. (2) } \\
\hline Polyplacophora & Polyplacophora \\
\hline $\begin{array}{l}\text { Chiton granosus }(7) \\
\text { Chaetopleura periviana (2) }\end{array}$ & Chiton granosus (1) \\
\hline CNIDARIA & CNIDARIA \\
\hline $\begin{array}{l}\text { Phymactis clematis (119) } \\
\text { Anthothoe chilensis (6) }\end{array}$ & Phymactis clematis (3) \\
\hline NEMERTEA (308) & NEMERTEA (330) \\
\hline
\end{tabular}

demonstrated by the nMDS (Fig. 2) and by the results of ANOSIM (R-statistic $=0.432, P=0.0024)$. SIMPER analysis revealed that the anemone Phymactis clematis and the bivalve Perumytilus purpuratus contributed the most to the differences between assemblages, each accounting for $19.34 \%$ of the differences (Table 2). Abundances of $P$. clematis were 119 in UH versus 3 in NH holdfasts, whereas abundances of $P$. purpuratus were 1077 in UH versus 82 in NH holdfasts (Table 1.). The number of species (S) was significantly different between the two types of holdfasts ( $\mathrm{F}=13.1, P<0.01$ ) but there were no significant differences in the Shannon-Wiener index ( $\left.H^{\prime}\right)(F=4.59, P=0.064)$.

The structure of the assemblages differed clearly between holdfasts in the old and new intertidal. There are only a few studies presenting data on the effects of earthquake-mediated coastal uplifts on intertidal organisms, although these studies have mostly been descriptive, using organisms such as sessile invertebrates and coralline algae as bioindicators of coastal uplift (e.g., Bodin \& Klinger 1986, Castilla \& Oliva 1990, Awata et al. 2008, Castilla et al. 2010). Kelp holdfasts have been recognized as ‘micro-ecosystems’ (Thiel \& Vásquez 2000), and the structure of their assemblages has commonly been used as a biomonitoring tools for assessing environmental stress (e.g., Jones 1972, Smith \& Simpson 1992, Sáez et al. 2012). However, to the extent of our

Table 2. SIMPER analysis of the species contributing most to dissimilarities in holdfast assemblages structure. Average BrayCurtis similarity was $23.18 \%$. XAbund 1 = average abundance of Uplifted Holdfasts; XAbund2 = average abundance of Non-Uplifted Holdfasts; $X D i s s=$ similarity average; $\%$ Contrib = percent contribution to overall similarity between the 2 types of holdfasts / Análisis SIMPER de las especies que contribuyen a las diferencias entre los ensambles asociados a discos. El promedio de disimilitud de Bray-Curtis fue $23,18 \%$. XAbund $1=$ promedio de abundancia de UH; XAbund $2=$ promedio de abundancia de $\mathrm{NH} ; \mathrm{XDiss}=$ similitud promedio; $\%$ Contrib = contribución porcentual de similitud general entre los 2 tipos de discos

\begin{tabular}{lccccc}
\hline Species & XAbund 1 & XAbund 2 & XDiss & \%Contrib & \%Cum \\
\hline Phymactis clematis & 4.79 & 1.39 & 2.56 & 11.03 & 11.03 \\
Perumytilus purpuratus & 6.98 & 4.42 & 1.93 & 8.31 & 19.34 \\
Amphipoda & 5.68 & 3.5 & 1.64 & 7.09 & 26.43 \\
Anthothoe chilensis & 1.95 & 0 & 1.46 & 6.31 & 32.74 \\
Isopoda & 3.95 & 2.08 & 1.41 & 6.07 & 38.8 \\
Lumbrineridae & 1.79 & 0 & 1.35 & 5.81 & 44.61 \\
Acanthocyclus gayi & 4.32 & 2.56 & 1.32 & 5.68 & 50.29 \\
Terebellidae & 3.93 & 2.2 & 1.3 & 5.62 & 55.92 \\
Scurria scurra & 4.51 & 2.89 & 1.22 & 5.25 & 61.17 \\
Homalaspis plana & 0 & 1.61 & 1.21 & 5.22 & 66.39 \\
\hline
\end{tabular}

Vol. 49, № 1, 2014 


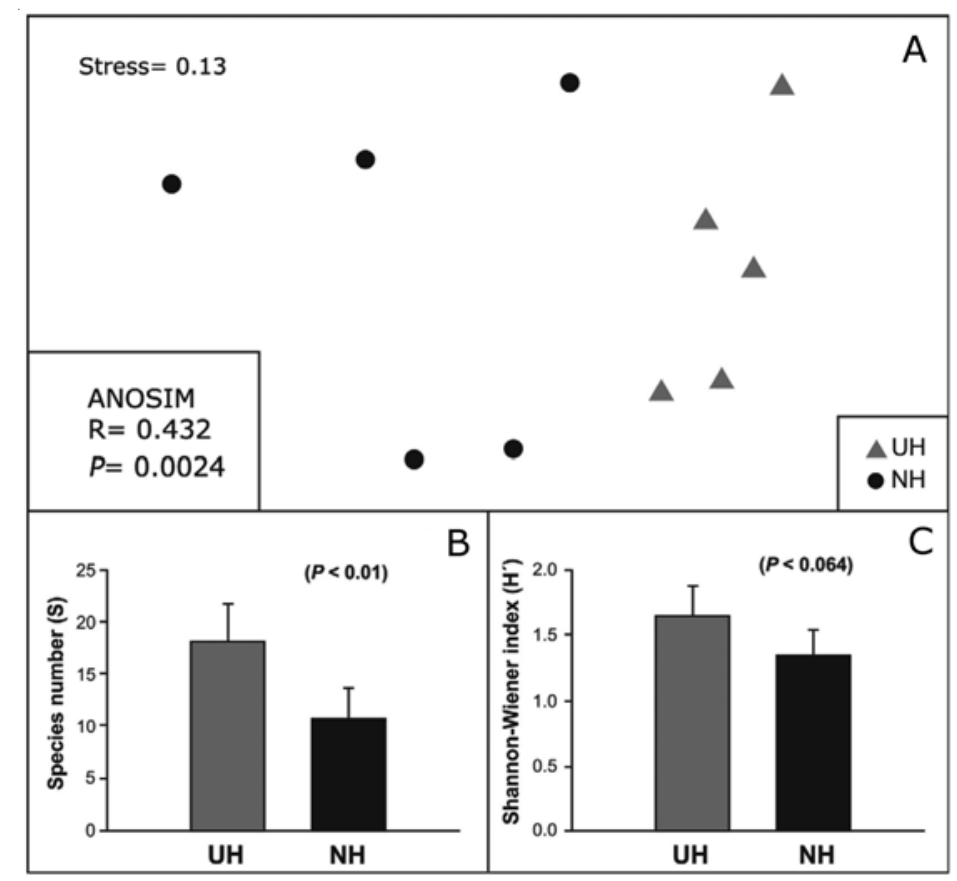

Figure 2. A) Non-parametric multidimensional scaling plot (nMDS) and ANOSIM of the invertebrate assemblages associated with UH (Uplifted) and NH (Non-Uplifted) holdfasts. B) Species number. C) Shannon-Wiener index of associated fauna inhabiting the 2 types of $L$. spicata holdfasts. Bars indicate standard error / A) Análisis no paramétrico de escalamiento multidimensional (nMDS) y análisis de similitudes (ANOSIM) que describen los ensambles de invertebrados de Discos Levantados (UH) y Discos No-levantados (NH). B) Número de especies. C) Índice de Shannon-Wiener correspondiente a la fauna asociada en los 2 tipos de discos de L. spicata. Barras indican error estándar

knowledge, this is the first study showing effects of coastal uplift on the composition of invertebrate assemblages inhabiting kelp holdfasts. It is also the first to assess a rare primary succession occurring in a new intertidal belt.

The bivalve $P$. purpuratus and the anemone $P$. clematis contributed the most to the differences in the structure of the assemblages, mainly because these species were more abundant in UH. One possible reason is that the assemblages in $\mathrm{NH}$ were much younger than their $\mathrm{UH}$ counterpart and so the stage of succession may drive the differences (Smith et al. 1996). However, it has been observed that $P$. purpuratus is capable of withstanding long periods of desiccation and high salinity; moreover, they have been observed to occasionally occupy positions in the high intertidal, where seawater reach is only sporadic and limited (Vial et al. 1992). Phymactis clematis has also been found to be tolerant to long periods of desiccation and high salinity (Acuña \& Zamponi 1995). Furthermore, and more importantly, P. clematis preferentially preys on mussels such as Brachydontes rodriguezi (Acuña \& Zamponi 1996), which might suggest predator-prey links between $P$. clematis and $P$. purpuratus. In the intertidal, $L$. spicata holdfasts provide refuge from wave action during high tide, and from desiccation during low tide due to water retention in its complex structure (Vásquez \& Santelices 1984). Our data suggest that a drastic coastal uplift, produced by natural events such as the mega-earthquake in 2010, may benefit holdfast species with high tolerances to desiccation and high salinity, and that UH still provide suitable refuge for their survival and development.

The NH in the new intertidal belt had lower species richness in relation to the UH. These results are in agreement with the observations made by Vásquez \& Santelices (1984) and Villouta \& Santelices (1986), who found that new holdfasts contained lower species richness. Our data indicates that only one species, the polychaete worm Sabellariidae sp., had higher abundance in $\mathrm{NH}$ than in UH. Sabellariids are fast-growing, detritivorous and filter-feeding worms, which need high humidity and regular water exposure (see Knight-Jones 1981). Their high abundance in NH might suggest they are pioneer species of this primary succession. 
This investigation provides new insights into the effects of natural events such as drastic coastal uplift in littoral communities. Our data suggest that holdfasts lifted within the ranges observed in the 2010 earthquake in ' $\mathrm{La}$ Desembocadura' can still remain as active 'microecosystems'; however, the species benefiting will be those that can survive and withstand long periods of desiccation and high salinity. On the other hand, young holdfasts in the new intertidal belt provide a new refuge for invertebrate assemblages and provide the possibility for a rare primary succession. In Chile, coastal uplifts caused by telluric events can cover extended regions of coastline and might induce massive changes in the structure of assemblages that still remain unknown. In the future, replication of this study using greater sampling efforts and higher taxonomic resolution will help to better elucidate the macro-ecological implications of such rare events.

\section{ACKNOWLEDGMENTS}

We thank the contribution of two anonymous referees that helped improving this manuscript. This research was partially supported by FONDECYT Project 11110437 (CONICYT) to ECM. We also thank CONICYT Becas Chile Scholarship (72110557) for financial support for doctoral studies to CAS. We are grateful to Ricardo Jeldres, Ariel Cáceres, María Monsalvez and Solange Pacheco for their help in the field and laboratory analyses.

\section{LITERATURE CITED}

Acuña FH \& MO Zamponi. 1995. Ecology of intertidal sea anemones, density, dispersion and autoecology of Phymactis clematis Dana, 1849 (Anthozoa, Actiniaria). Ciencias Marinas 21: 1-12.

Acuña FH \& MO Zamponi. 1996. Trophic ecology of the intertidal sea anemones Phymactis clematis Dana, 1849, Aulactinia marplatensis (Zamponi, 1977) and A. reynaudi (Milne-Edwards, 1857) (Actiniaria: Actiniidae): Relationships between sea anemones and their prey. Ciencias Marinas 22: 397-413.

Awata Y, S Toda, H Kaneda, T Azuma, H Horikawa, M Shishikura \& T Echigo. 2008. Coastal deformation associated with the 2007 NotoHanto earthquake, central Japan, estimated from uplifted and subsided intertidal organisms. Earth Planets and Space 60: 1059-1062.

Bodin P \& T Klinger. 1986. Coastal uplift and mortality of intertidal organisms caused by the September 1985 Mexico earthquakes. Science 233: 1071-1073.
Cancino JM \& B Santelices. 1984. Importancia ecológica de los discos de Lessonia nigrescens Bory (Phaeophyta) en Chile central. Revista Chilena de Historia Natural 57: 2333.

Castilla JC. 1988. Earthquake-caused coastal uplift and its effects on rocky intertidal kelp communities. Science 242: 440-443.

Castilla JC \& D Oliva. 1990. Ecological consequences of coseismic uplift on the intertidal kelp belts of Lessonia nigrescens in central Chile. Estuarine Coastal and Shelf Science 31: 45-56.

Castilla JC, PH Manríquez \& A Camaño. 2010. Effects of rocky shore coseismic uplift and the 2010 Chilean megaearthquake on intertidal biomarker species. Marine Ecology Progress Series 418: 17-23.

Clarke KR. 1993. Non-parametric multivariate analyses of changes in community structure. Australian Journal of Ecology 18: 117-143.

Clarke KR, PJ Somerfield \& MG Chapman. 2006. On resemblance measures for ecological studies, including taxonomic dissimilarities and a zero-adjusted Bray-Curtis coefficient for denuded assemblages. Journal of Experimental Marine Biology and Ecology 330: 55-80.

Farías M, G Vargas, A Tassara, S Carretier, S Baize, D Melnick \& K Bataille. 2010. Land-Level changes produced by the Mw 8.82010 Chilean earthquake. Science 329: 916-916.

González A, J Beltrán, L Hiriart-Bertrand, V Flores, B de Reviers, JA Correa \& B Santelices. 2012. Identification of cryptic species in the Lessonia nigrescens complex (Phaeophyceae, Laminariales). Journal of Phycology 48: 1153-1165.

Jaramillo E, JE Dugan, DM Hubbard, D Melnick, M Manzano, C Duarte, C Campos \& R Sanchez. 2012. Ecological implications of extreme events: footprints of the 2010 earthquake along the Chilean coast. PLoS ONE 7: e35348.

Jones DJ. 1972. Changes in ecological balance of invertebrate communities in kelp holdfast habitats of some polluted North-Sea waters. Helgoländer Wissenschaftliche Meeresuntersuchungen 23: 248-260.

Knight-Jones PE. 1981. Behavior, setal inversion and phylogeny of Sabellida (Polychaeta). Zoologica Scripta 10: 183-202.

Melnick D, M Cisternas, M Moreno \& R Norambuena. 2012. Estimating coseismic coastal uplift with an intertidal mussel: calibration for the 2010 Maule Chile earthquake ( $\mathrm{M}-\mathrm{w}=8.8)$. Quaternary Science Reviews 42: 29-42.

Ojeda FP \& B Santelices. 1984. Ecological dominance of Lessonia nigrescens (Phaeophyta) in central Chile. Marine Ecology Progress Series 19: 83-91. 
Sáez CA, A Pérez-Matus, MG Lobos, D Oliva, JA Vásquez \& M Bravo. 2012. Environmental assessment in a shallow subtidal rocky habitat: Approach coupling chemical and ecological tools. Chemistry and Ecology 28: 1-15.

Smith SDA. 2000. Evaluating stress in rocky shore and shallow reef habitats using the macrofauna of kelp holdfasts. Journal of Aquatic Ecosystem Stress and Recovery 7: 259-272.

Smith SDA \& RD Simpson. 1992. Monitoring the shallow Marine Biology: An Annual Review 45: 195-344.

Tuya F, K Larsen \& V Platt. 2011. Patterns of abundance and assemblage structure of epifauna inhabiting two morphologically different kelp holdfasts. Hydrobiologia 658: 373-382.

Vargas G, M Farías, S Carretier, A Tassara, S Baize \& D Melnick. 2011. Coastal uplift and tsunami effects associated to the 2010 Mw8.8 Maule earthquake in Central Chile. Andean Geology 38: 219-238.
Vásquez JA \& B Santelices. 1984. Comunidades de macroinvertebrados en discos de adhesión de Lessonia nigrescens en Chile central. Revista Chilena de Historia Natural 57: 131-154.

Vial MV, RW Simpfendorfer, DA Lopez, ML Gonzalez \& K Oelckers. 1992. Metabolic responses of the intertidal mussel Perumytilus purpuratus (Lamarck) in emersion and immersion. Journal of Experimental Marine Biology and Ecology 159: 191-201.

Villouta E \& B Santelices. 1986. Lessonia trabeculata sp. nov (Laminariales, Phaeophyta), a new kelp from Chile. Phycologia 25: 81-86.

Received 02 January 2013 and accepted 20 November 2013

Associate Editor: Pilar Muñoz M. 